\title{
Determinants of Returns of Cross Listed Firms: Evidence from Indian GDR
}

\author{
${ }^{1}$ Prof. Pallavi Chopade, ${ }^{2}$ Ms. Garima Sisodia \\ ${ }^{1}$ Asst. Professor, Bharati Vidyapeeth University Institute of Management and Entrepreneurship Development, \\ Pune-411038 \\ ${ }^{2}$ Doctoral Research Scholar, IFHE, Hyderabad
}

\begin{abstract}
The present paper attempts to find out the role of two market involved with the depositary receipts. The depositary receipts are traded independently in the host market where they are issued. At the same time these depositary receipts are equivalent to the underlying stocks in the home country. The study want to find out if the returns generated from these depositary receipts are affected by both the markets, and if so which market plays predominant role in determining these returns. Returns of 35 GDR of Indian companies have been studied for the period April 2009 to April 2010. The study reveals that the returns from the underlying securities affect the returns of the respective GDRs but not vice-versa. The study further shows that the informational factors of the home market (market where securities are issued) have more prominent effect on the GDR returns than the host market (market where GDR are issued).
\end{abstract}

\section{Introduction}

The financial markets in general and the equity market in particular have now become more closely interlinked the world over than ever before despite the differences in risk perceptions of the markets or the country profiles. The dynamics of cross-country trade and payments have evolved to such an extent that the economic slowdown of a country is bound to affect its trading partners as clearly discernable from the leading movement in the global stock prices. The close integration between the emerging and the developed markets has even led to sentiment spillover from one market to another. A possible contributor to the similar volatility profile across the markets is the listing of stocks at dual or multiple stock exchanges all over the globe (Bennett and Keller, 1988). Their movement in tandem powered by the instinct of arbitrage could have contributed to the emergent cross-country co-movement of stock prices.

With the financial sector reforms initiated in 1991, Indian stock market has since joined the integration process. The inflow of foreign funds with entry of foreign institutional investors (FII) has transformed the style of functioning of the Indian stock market. Moreover, it has forged an important linkage between the capital and the forex markets. During this phase, investment norms for non-resident Indians (NRIs), persons of Indian origin (PIOs) and overseas corporate bodies (OCBs) have been largely liberalized, inter alia, with permission to purchase of shares without any prior approval from the RBI. Further, the Indian corporate have been allowed to tap the global market with global depository receipt (GDR), American depository receipt (ADR) and foreign currency convertible bond (FCCB) since 1993. On the other hand, the world-class facilities provided by the newly constituted National Stock Exchange (NSE) have unleashed competitive forces, prompting other exchanges to go for automation and screen based trading. All these have ushered in an era of integration and globalization of the hitherto insulated and segmented Indian stock market.

\section{Genesis of Depository Receipts: The Indian Experience}

Starting with the maiden issue of the Reliance Industries in May 1992, around 88-odd Indian companies have so far tapped the global market. Indeed, India has the distinction of issuing the maximum number of DRs among the emerging economies. The genesis of Indian multinational corporations (MNCs) with not only international operations but also a global ownership is logical fallout of this process.

While bunching of DR issues took place in the early 1990s possibly in view of the pent-up overseas demand for Indian papers, it seemed to have been primarily motivated by the existing costly procedure of floatation in the domestic market (Patil, 1994). Initially GDR was the preferred mode with the majority of listings in the Luxembourg or the London Stock Exchange in view of their less stringent disclosure requirements vis-à-vis the requirements under the US GAAP (i.e., Generally Accepted Accounting Principle). Besides, a majority of the Indian GDRs were issued pursuant to the US Rule 144A and/or Regulation S of the Securities Exchange Commission, which enabled their trading in the US market too mainly through the PORTAL system. Nevertheless, ADR has since emerged as the star attraction due to its higher global visibility, particularly for the new-economy stocks, with issues listed in NYSE and Nasdaq so far. While the ownership 
pattern of Indian GDR/ADR is not clear, both individual and foreign ownerships were in general found to be higher in London than in the US as per the Paris-based World Federation of Exchanges (FIBV) Survey (1999). Initially, companies seeking to float DRs were required to obtain prior permission from the Department of Economic Affairs, Ministry of Finance, the Government of India (GOI). To be eligible, companies should have a consistent track record of good performance for a minimum period of 3 years. The infrastructure companies were exempted from the latter requirement in June 1996. The restrictions on number of DR issues were also removed in June 1996. The Euro issue proceeds were subject to a number of end-use restrictions modified from time to time before their withdrawal in May 1998. However, such proceeds were not to be invested in stock market and real estate. In December 1999 Indian software companies, in March 2000 other knowledge-based companies, and in April 2001 all types of companies were permitted to undertake overseas business acquisition through ADR/GDR stock swap. In January 2000, companies were made free to access the GDR/ADR market through an automatic route operated by the RBI, without the prior approval of the GOI or the track record condition. The issuing company needs to furnish full particulars of the issue to the GOI and the RBI within 30 days of completion of such transactions. Similarly companies were allowed in phases to utilize, without any prior approval, part of the DR proceeds for overseas investment and finally up to 100 per cent of the proceeds from February 2001.

DRs can be redeemed at the price of the corresponding shares of the issuing company ruling on the BSE or the NSE on the date of redemption. Similar norms apply to conversion of FCCBs. The ordinary shares and FCCBs issued against the DRs are treated as foreign direct investment (FDI). The aggregate of foreign equity participation directly or indirectly through the DR mechanism should not exceed 51 per cent of the issued and subscribed capital of the issuing company. Two-way fungibility in DR issues of Indian companies has been introduced from February 13, 2002 whereby converted local shares could be reconverted into DR subject to sectoral caps on FDI.

\section{Objectives:}

- To find out if the returns of the GDR effects the underlying securities returns or vice-versa.

○ To find out the relative effect of "informational factor" of Indian market and the host market in which of Depositary Receipts are issued, on the GDR returns.

\section{Sources of Data:}

The purpose of present study is to find out the effect of both home and host market on the GDR returns. The daily prices of the Indian GDRs has been collected from www.adrbyn.com, underlying stock's prices and S \& P nifty 50 has been collected from prowess, exchange rates has been collected from www.oanda.com, closing prices of indices has been taken from www.econstat.com. The data covered the period of $13^{\text {th }}$ April 2008 to $13^{\text {th }}$ April 2009. The GDRs included for the study are listed below. The exchanges in which they are listed, the major index and currency of the respective exchanges are also given as follows;

Table: 1 List of Indian GDR

\begin{tabular}{|l|l|lr|l|l|}
\hline & Indian GDR & Listed In & Major Index & Currency \\
\hline 1 & Amtek Auto & $\begin{array}{l}\text { London } \\
\text { Exchange }\end{array}$ & Stock & FTSE 100 & British pound \\
\hline 2 & Axis Bank & $\begin{array}{l}\text { London } \\
\text { Exchange }\end{array}$ & Stock & FTSE 100 & British pound \\
\hline 3 & Subex & $\begin{array}{l}\text { London } \\
\text { Exchange }\end{array}$ & Stock & FTSE 100 & British pound \\
\hline 4 & Alps Industries & $\begin{array}{l}\text { Luxembourg } \\
\text { Exchange }\end{array}$ & Stock & LuxX Index & Euro \\
\hline 5 & Apollo Hospitals & $\begin{array}{l}\text { Luxembourg } \\
\text { Exchange }\end{array}$ & Stock & LuxX Index & Euro \\
\hline 6 & Balrampur Chini Mills & $\begin{array}{l}\text { Luxembourg } \\
\text { Exchange }\end{array}$ & Stock & LuxX Index & Euro \\
\hline 7 & $\begin{array}{l}\text { BSEL } \text { Realty } \\
\text { Infrastructure }\end{array}$ & $\begin{array}{l}\text { Luxembourg } \\
\text { Exchange }\end{array}$ & Stock & LuxX Index & Euro \\
\hline 8 & Cipla & $\begin{array}{l}\text { Luxembourg } \\
\text { Exchange }\end{array}$ & Stock & LuxX Index & Euro \\
\hline 9 & Crew B.O.S. Products & $\begin{array}{l}\text { Luxembourg } \\
\text { Exchange }\end{array}$ & Stock & LuxX Index & Euro \\
\hline 10 & Emco & Luxembourg & Stock & LuxX Index & Euro \\
\hline
\end{tabular}


Determinants of Returns of Cross Listed Firms: Evidence from Indian GDR

\begin{tabular}{|c|c|c|c|c|}
\hline & & Exchange & & \\
\hline 11 & Hinduja Foundries & $\begin{array}{l}\text { Luxembourg Stock } \\
\text { Exchange }\end{array}$ & LuxX Index & Euro \\
\hline 12 & IKF Technologies & $\begin{array}{l}\text { Luxembourg Stock } \\
\text { Exchange }\end{array}$ & LuxX Index & Euro \\
\hline 13 & K Sera Sera & $\begin{array}{l}\text { Luxembourg Stock } \\
\text { Exchange }\end{array}$ & LuxX Index & Euro \\
\hline 14 & KLG Systel & $\begin{array}{ll}\text { Luxembourg } & \text { Stock } \\
\text { Exchange } & \end{array}$ & LuxX Index & Euro \\
\hline 15 & $\begin{array}{ll}\text { Micro } & \text { Technologies } \\
\text { (India) } & \\
\end{array}$ & $\begin{array}{l}\text { Luxembourg Stock } \\
\text { Exchange }\end{array}$ & LuxX Index & Euro \\
\hline 16 & ORG Informatic & $\begin{array}{l}\text { Luxembourg Stock } \\
\text { Exchange }\end{array}$ & LuxX Index & Euro \\
\hline 17 & $\begin{array}{l}\text { Paramount } \\
\text { Communications }\end{array}$ & $\begin{array}{l}\text { Luxembourg Stock } \\
\text { Exchange }\end{array}$ & LuxX Index & Euro \\
\hline 18 & Sanraa Media & $\begin{array}{l}\text { Luxembourg } \text { Stock } \\
\text { Exchange }\end{array}$ & LuxX Index & Euro \\
\hline 19 & Shah Alloys & $\begin{array}{l}\text { Luxembourg Stock } \\
\text { Exchange }\end{array}$ & LuxX Index & Euro \\
\hline 20 & $\begin{array}{ll}\text { Sujana } & \text { Universal } \\
\text { Industries } & \\
\end{array}$ & $\begin{array}{l}\text { Luxembourg Stock } \\
\text { Exchange }\end{array}$ & LuxX Index & Euro \\
\hline 21 & $\begin{array}{ccc}\text { Taneja } & \text { Aerospace } \& \\
\text { Aviation } & & \\
\end{array}$ & $\begin{array}{l}\text { Luxembourg Stock } \\
\text { Exchange }\end{array}$ & LuxX Index & Euro \\
\hline 22 & Teledata Informatics & $\begin{array}{l}\text { Luxembourg Stock } \\
\text { Exchange }\end{array}$ & LuxX Index & Euro \\
\hline 23 & Tricom India & $\begin{array}{l}\text { Luxembourg Stock } \\
\text { Exchange }\end{array}$ & LuxX Index & Euro \\
\hline 24 & Wanbury & $\begin{array}{l}\text { Luxembourg Stock } \\
\text { Exchange }\end{array}$ & LuxX Index & Euro \\
\hline 25 & Infosys Technologies & $\begin{array}{l}\text { NASDAQ } \\
\text { Market }\end{array}$ & $\begin{array}{l}\text { NASDAQ } \\
\text { Composite } \\
\text { Index } \\
\end{array}$ & US Dollar \\
\hline 26 & Rediff.com India & $\begin{array}{l}\text { NASDAQ } \\
\text { Market }\end{array}$ & $\begin{array}{l}\text { NASDAQ } \\
\text { Composite } \\
\text { Index }\end{array}$ & US Dollar \\
\hline 27 & SIFY & $\begin{array}{l}\text { NASDAQ } \\
\text { Market }\end{array}$ & $\begin{array}{l}\text { NASDAQ } \\
\text { Composite } \\
\text { Index } \\
\end{array}$ & US Dollar \\
\hline 28 & Dr. Reddy's Laboratories & $\begin{array}{l}\text { New York Stock } \\
\text { Exchange }\end{array}$ & $\begin{array}{ll}\text { Dow } & \text { Jones } \\
\text { Industrial } \\
\text { Average } \\
\text { Index }\end{array}$ & US Dollar \\
\hline 29 & HDFC Bank & $\begin{array}{l}\text { New York Stock } \\
\text { Exchange }\end{array}$ & $\begin{array}{ll}\text { Dow } & \text { Jones } \\
\text { Industrial } & \\
\text { Average } & (30) \\
\text { Index } & \\
\end{array}$ & US Dollar \\
\hline 30 & Patni Computer Systems & $\begin{array}{l}\text { New York Stock } \\
\text { Exchange }\end{array}$ & $\begin{array}{l}\text { Dow Jones } \\
\text { Industrial } \\
\text { Average } \\
\text { Index }\end{array}$ & US Dollar \\
\hline 31 & $\begin{array}{ll}\text { Satyam } & \text { Computer } \\
\text { Services } & \end{array}$ & $\begin{array}{l}\text { New York Stock } \\
\text { Exchange }\end{array}$ & $\begin{array}{ll}\text { Dow } & \text { Jones } \\
\text { Industrial } & \\
\text { Average } & (30) \\
\text { Index } & \end{array}$ & US Dollar \\
\hline 32 & Sterlite Industries & $\begin{array}{l}\text { New York Stock } \\
\text { Exchange }\end{array}$ & $\begin{array}{ll}\text { Dow } & \text { Jones } \\
\text { Industrial } & \\
\text { Average } & (30) \\
\text { Index } & \\
\end{array}$ & US Dollar \\
\hline
\end{tabular}




\begin{tabular}{|l|l|l|l|l|}
\hline 33 & Wipro & $\begin{array}{l}\text { New York Stock } \\
\text { Exchange }\end{array}$ & $\begin{array}{l}\text { Dow Industrial } \\
\text { Average (30) } \\
\text { Index }\end{array}$ & US Dollar \\
\hline 34 & WNS Holdings & $\begin{array}{l}\text { New York Stock } \\
\text { Exchange }\end{array}$ & $\begin{array}{l}\text { Dow Industrial Jones } \\
\text { Average (30) } \\
\text { Index }\end{array}$ & US Dollar \\
\hline 35 & Visesh Infotecnics & Singapore Exchange & $\begin{array}{l}\text { Straits Times } \\
\text { Index }\end{array}$ & Singapore Dollar \\
\hline
\end{tabular}

\section{Methodology} test them.

A number of hypotheses were formulated. They are given below along with the methodology used to

$\mathrm{H}_{01 \mathrm{a}}$ : The returns from the Indian GDRs have unit roots

The stationarity of the all the GDR returns, securities returns and major index returns were checked with Augumented Dickey Fuller Method.

$\mathrm{H}_{02 \mathrm{a}}$ : The returns from the Indian GDRs does not Granger cause the returns from underlying securities $\mathrm{H}_{02 \mathrm{~b}}$ : The returns from underlying securities does not Granger cause the returns from the respective Indian GDRs

Granger Causality test was used to find out the underlying causality relationship between returns of Indian GDRs and their respective underlying stocks.

$\mathrm{H}_{03 \mathrm{a}}$ : The returns from the Indian GDRs are effected more by the host market in which they are listed than the home market in which the underlying securities are issued.

This hypothesis is tested with the help of model developed by Shmuel Baruch, G. Andrew Karolyi, and Michael L. Lemmon (2003)

\section{Findings}

First of all, for comparison purpose Indian GDRs and closing prices of indices are converted into Indian Rupees. All the returns from Indian GDRs, underline securities and the respective indices were checked for stationarity with the help of Dickey Fuller Test. All the return series were found to be stationary. Granger Causality test was conducted for checking whether prices of Indian GDRs are affecting the prices of underline stocks or vice versa. The results obtained are given below;

Table: 2 Causality pattern between Security returns and their GDR returns

\begin{tabular}{|c|c|c|c|}
\hline Company & $\begin{array}{l}\text { Granger's } \\
\mathrm{F}\end{array}$ & p-value & Causality Conclusion \\
\hline ALPS & 41.5685 & $2.5 \mathrm{E}-15$ & Security returns $\rightarrow$ DR returns \\
\hline AMTEK & 70.0647 & $2.2 \mathrm{E}-14$ & Security returns $\rightarrow$ DR returns \\
\hline APPOLLO & 22.1098 & $5.4 \mathrm{E}-06$ & Security returns $\rightarrow$ DR returns \\
\hline AXIS & 8.60657 & $2.5 \mathrm{E}-05$ & Security returns $\rightarrow$ DR returns \\
\hline BSEL & 47.2534 & $6.2 \mathrm{E}-17$ & Security returns $\rightarrow$ DR returns \\
\hline CIPLA & 7.66908 & 0.00065 & Security returns $\rightarrow$ DR returns \\
\hline CREW & 53.6787 & $1.2 \mathrm{E}-18$ & Security returns $\rightarrow$ DR returns \\
\hline DR & 13.8540 & $2.8 \mathrm{E}-06$ & Security returns $\rightarrow$ DR returns \\
\hline EMCO & 35.6070 & $1.5 \mathrm{E}-08$ & Security returns $\rightarrow$ DR returns \\
\hline HDFC & 2.02793 & 0.07765 & Security returns $\rightarrow$ DR returns \\
\hline HINDUJA & 4.74539 & 0.00992 & Security returns $\rightarrow$ DR returns \\
\hline INFOSYS & 2.60986 & 0.07660 & Security returns $\rightarrow$ DR returns \\
\hline KLG & 40.9290 & 3.8E-15 & Security returns $\rightarrow$ DR returns \\
\hline KSERA & 28.9915 & $1.7 \mathrm{E}-11$ & Security returns $\rightarrow$ DR returns \\
\hline MICRO & 17.3168 & $5.1 \mathrm{E}-05$ & Security returns $\rightarrow$ DR returns \\
\hline PARAMOUNT & 5.44952 & 0.00136 & Security returns $\rightarrow$ DR returns \\
\hline
\end{tabular}


Determinants of Returns of Cross Listed Firms: Evidence from Indian GDR

\begin{tabular}{|l|l|l|l|}
\hline PATNI & 6.14478 & 0.00056 & Security returns $\rightarrow$ DR returns \\
\hline SATYAM & 37.0696 & $7.6 \mathrm{E}-09$ & Security returns $\rightarrow$ DR returns \\
\hline SHAH & 17.4204 & $1.4 \mathrm{E}-07$ & Security returns $\rightarrow$ DR returns \\
\hline STERILITE & 34.2063 & $2.5 \mathrm{E}-08$ & Security returns $\rightarrow$ DR returns \\
\hline SUBEX & 2.74543 & 0.09941 & Security returns $\rightarrow$ DR returns \\
\hline SUJANA & 2.52348 & 0.08329 & Security returns $\rightarrow$ DR returns \\
\hline VISESH & 2.83234 & 0.06176 & Security returns $\rightarrow$ DR returns \\
\hline WANBURY & 33.8063 & $3.0 \mathrm{E}-08$ & Security returns $\rightarrow$ DR returns \\
\hline WIPRO & 0.55237 & 0.45839 & No conclusions \\
\hline
\end{tabular}

Table 3: Causality pattern between GDR returns and the underlying security returns

\begin{tabular}{|c|c|c|c|}
\hline Company & Granger's F & p-value & Causality Conclusion \\
\hline ALPS & 0.76701 & 0.46606 & No conclusions \\
\hline AMTEK & 0.03210 & 0.85803 & No conclusions \\
\hline APPOLLO & 0.00014 & 0.99059 & No conclusions \\
\hline AXIS & 0.87933 & 0.45317 & No conclusions \\
\hline BSEL & 1.96941 & 0.14283 & No conclusions \\
\hline CIPLA & 0.16172 & 0.85081 & No conclusions \\
\hline CREW & 0.25439 & 0.77569 & No conclusions \\
\hline DR & 1.73181 & 0.18018 & No conclusions \\
\hline EMCO & 0.19267 & 0.66130 & No conclusions \\
\hline HDFC & 0.74137 & 0.59359 & No conclusions \\
\hline HINDUJA & 0.47570 & 0.62231 & No conclusions \\
\hline INFOSYS & 0.11372 & 0.89257 & No conclusions \\
\hline KLG & 2.06666 & 0.12989 & No conclusions \\
\hline KSERA & 1.79550 & 0.16929 & No conclusions \\
\hline MICRO & 0.34761 & 0.55627 & No conclusions \\
\hline PARAMOUNT & 4.98265 & 0.00248 & DR returns $\rightarrow$ Security returns \\
\hline PATNI & 2.34100 & 0.07531 & DR returns $\rightarrow$ Security returns \\
\hline SATYAM & 0.01724 & 0.89570 & No conclusions \\
\hline SHAH & 1.00043 & 0.36995 & No conclusions \\
\hline STERILITE & 2.12779 & 0.14653 & No conclusions \\
\hline SUBEX & 0.98230 & 0.32306 & No conclusions \\
\hline SUJANA & 0.82574 & 0.43972 & No conclusions \\
\hline VISESH & 0.07179 & 0.93076 & No conclusions \\
\hline WANBURY & 1.01716 & 0.31465 & No conclusions \\
\hline WIPRO & 0.19652 & 0.65812 & No conclusions \\
\hline
\end{tabular}

The results show that the security returns have an impact on the respective GDR returns. But it is not true other way round. In two of the cases two-way-causality was found. These securities were dropped from the regression analysis conducted in next stage.

To find out the relative effect of "informational factor" of Indian market and the host market in which of Depositary Receipts are issued, on the GDR returns a model developed by Shmuel Baruch, G. Andrew Karolyi, and Michael L. Lemmon (2003) has been used.

To perform the variance decomposition we first estimate the following two time-series regressions for each GDR:

$\mathrm{R}_{\mathrm{it}}=\alpha+\sum \beta_{\mathrm{i}, \mathrm{H}, \mathrm{t}+\mathrm{k}} \mathrm{R}_{\text {home, } \mathrm{t}+\mathrm{k}}+\varepsilon_{\mathrm{it}}$ 
$\mathbf{R}_{\mathrm{it}}=\alpha+\sum \beta_{\mathrm{i}, \mathrm{H}, \mathrm{t+ \textrm {k }}} \mathbf{R}_{\text {home }, \mathrm{t}+\mathrm{k}}+\sum \beta_{\mathrm{i}, \mathrm{H}, \mathrm{t}+\mathrm{k}} \mathbf{R}_{\text {host }, \mathrm{t}+\mathrm{k}}+\varepsilon_{\mathrm{it}}$

where $\mathrm{R}_{\mathrm{it}}$ is the return (measured in INR) in period $t, \mathrm{R}_{\text {Home,t+k }}$ is the return denominated in INR on the market index (here nifty) in the stock's home country in period $t+k$, and $R_{U S, t+k}$ is the INR-denominated return on the host market index in period $\mathrm{t}+\mathrm{k}$. The lead and lag terms in the regressions are used to account for nonsynchronous trading across markets in different time zones.

The first regression in equation is considered the restricted regression and the second regression in equation is considered the unrestricted regression. Assuming observations for the stock, six regressors in the unrestricted model, and three restrictions, we compute an F-statistic for each stock that measures the explanatory power of the unrestricted model relative to the explanatory power of the restricted model as follows:

$$
\frac{\left(R_{U R}^{2}-R_{R}^{2}\right) / 3}{\left(1-R_{U R}^{2}\right) /(n-6)}
$$

The results obtained are given in the table below;

Table 4:

\begin{tabular}{|l|l|l|l|l|l|}
\hline & & $\mathrm{R}_{\mathrm{UR}}^{2}$ & $\mathrm{R}_{\mathrm{R}}^{2}$ & $\mathrm{~F}$ (calculated) & $\mathrm{F}$ (table value) \\
\hline 1 & Alps Industries & 0.060601 & 0.060494 & 0.006162852 & 2.155302 \\
\hline 2 & Amtek Auto & 0.059448 & 0.058567 & 0.050238179 & 2.155302 \\
\hline 3 & Apollo Hospitals & 0.033632 & 0.031871 & 0.098375528 & 2.155302 \\
\hline 4 & Axis Bank & 0.108486 & 0.103053 & 0.327033092 & 2.155302 \\
\hline 5 & Balrampur Chini Mills & 0.041836 & 0.041501 & 0.018861842 & 2.155302 \\
\hline 6 & BSEL Infrastructure Realty & 0.097747 & 0.095895 & 0.110817405 & 2.155302 \\
\hline 7 & Cipla & 0.005165 & 0.002795 & 0.128675399 & 2.155302 \\
\hline 8 & Crew B.O.S. Products & 0.06035 & 0.057327 & 0.173702303 & 2.155302 \\
\hline 9 & Dr. Reddy's Laboratories & 0.010995 & 0.010848 & 0.007590928 & 2.158307 \\
\hline 10 & Emco & 0.108686 & 0.11067 & -0.120193452 & 2.155302 \\
\hline 11 & HDFC Bank & 0.099948 & 0.084509 & 0.874847733 & 2.158307 \\
\hline 12 & Hinduja Foundries & 0.057501 & 0.052747 & 0.272406378 & 2.155302 \\
\hline 13 & IKF Technologies & 0.083584 & 0.083393 & 0.011275941 & 2.155302 \\
\hline 14 & Infosys Technologies & 0.062969 & 0.036124 & 1.461085488 & 2.158307 \\
\hline 15 & K Sera Sera & 0.053461 & 0.05213 & 0.075961921 & 2.155302 \\
\hline 16 & KLG Systel & 0.088135 & 0.084961 & 0.187938083 & 2.155302 \\
\hline 17 & Micro Technologies (India) & 0.071317 & 0.067536 & 0.219813648 & 2.155302 \\
\hline 18 & ORG Informatic & 0.029819 & 0.026021 & 0.211351906 & 2.155302 \\
\hline 19 & Rediff.com India & 0.059833 & 0.057105 & 0.147961271 & 2.158307 \\
\hline 20 & Sanraa Media & 0.034783 & 0.034216 & 0.031683277 & 2.155302 \\
\hline 21 & Satyam Computer Services & 0.023313 & 0.021271 & 0.106630903 & 2.158307 \\
\hline 22 & Shah Alloys & 0.023558 & 0.023393 & 0.009143451 & 2.155302 \\
\hline 23 & SIFY & 0.074718 & 0.070161 & 0.251148963 & 2.158307 \\
\hline 24 & Sterlite Industries & 0.110024 & 0.096179 & 0.793348783 & 2.158307 \\
\hline 25 & Subex & 0.050333 & 0.024824 & 1.450494052 & 2.155302 \\
\hline 26 & Sujana Universal Industries & 0.070383 & 0.062971 & 0.430558135 & 2.155302 \\
\hline 27 & Taneja Aerospace \& Aviation & 0.035731 & 0.035608 & 0.006904626 & 2.155302 \\
\hline 28 & Teledata Informatics & 0.04402 & 0.046123 & -0.118806789 & 2.155302 \\
\hline 29 & Tricom India & 0.04402 & 0.043145 & 0.049420939 & 2.155302 \\
\hline 30 & Visesh Infotecnics & 0.06515 & 0.062588 & 0.139743971 & 2.158307 \\
\hline & & & & \\
\hline
\end{tabular}




\begin{tabular}{|l|l|l|l|l|l|}
\hline 31 & Wanbury & 0.026241 & 0.026059 & 0.010099646 & 2.155302 \\
\hline 32 & Wipro & 0.101926 & 0.072343 & 1.679950115 & 2.158307 \\
\hline 33 & WNS Holdings & 0.00687 & 0.00205 & 0.247511059 & 2.158307 \\
\hline
\end{tabular}

Here it is clearly evident that in all the cases the information factor of the home country have dominant impact on the GDR Returns when compared to the host country.

\section{Conclusion:}

The study shows that the GDR returns are affected by the underlying securities return but not viceversa. Further it was found that the information of home country have more prominent affect on the GDR returns when compared to the information in the host country.

\section{References}

[1] Bennett, P. and Keller, J., 1988, 'The International Transmission of Stock Price Disruption in October 1987', Federal Reserve Bank of New York Quarterly Review, Summer, 17-33.

[2] Patil, R. H., 1994, 'Capital Market Developments', The Journal of the Indian Institute of Bankers, 65 (3), July-September, 106-110, 139. 